\title{
On facing the God-question in a pastoral theology of compassion: From imperialistic omni-categories to theopaschitic pathos-categories
}

\begin{abstract}
Author:
Daniel J. Louw ${ }^{1}$

Affiliation:

${ }^{1}$ Faculty of Theology,

Stellenbosch University,

Africa

Correspondence to:

Daniel Louw

Email:

djl@sun.ac.za

Postal address:

Paradyskloof Villas

14, Paradyskloofweg,

Stellenbosch 7600, South

Africa

Dates:

Received: 09 June 2015

Accepted: 12 Aug. 2015

Published: 14 Dec. 2015

How to cite this article:

Louw, D.J., 2015, 'On

facing the God-question

in a pastoral theology

of compassion: From

imperialistic omni-categories

to theopaschitic pathos-

categories', In die Skriflig

49(1), Art. \#1996, 15 pages.

http://dx.doi.org/10.4102/

ids.v49i1.1996
\end{abstract}

Note:

This article's research is based on work previously published by the author.

\section{Copyright:}

(c) 2015. The Authors. Licensee: AOSIS

OpenJournals. This work is licensed under the Creative Commons Attribution License.

Read online:
Many scholars in the 20th century warned against static, ontological and metaphysical schemata of interpretation, stemming from Hellenistic thinking with its impact on God images in Christian reflection. Against the background of new spiritual and philosophical phenomena like apatheism and anatheism, the question regarding the appropriateness of existing categories for God within the framework of pastoral theology surfaces. A paradigm shift from omni-categories to pathos-categories is proposed in order to deal with issues like human suffering, dignity and justice. In this regard, theopaschitic theology can play a decisive role in the reframing of existing static God-images stemming predominantly from the Roman-Greco world. The notion of a 'sustainable God' is introduced in order to reframe God's compassionate presence (ta splanchna) in terms of a continuum of infinitive interventions (infiniscience and the pneumatology of to-be-with).

Die dinamika van die God-vraagstuk in 'n pastorale teologie van medelye en omgee: Vanaf imperialistiese omni-kategorieë na teopasgitiese patos-kategorieë. Navorsers het telkemale in die twintigste eeu teen die impak van statiese, ontologiese en metafisiese skemas van interpretasie gewaarsku. Teïstiese denke is grootliks deur Hellenistiese denkkategorieë bepaal. Teen die agtergrond van nuwe filosofiese verskynsels soos apateïsme en anateïsme en die invloed daarvan op die verskillende vorms van spiritualiteitsdenke, duik die vraag op na die toepaslikheid en relevansie van bestaande, geykte denkkategorië vir die Christelike verstaan van God. Die vraagstuk van lyding, menswaardigheid en geregtigheid stel nuwe eise aan 'n pastorale teologie wat met kontekstuele lewensvraagstukke erns maak. In die lig hiervan word 'n paradigmaskuif in teologisering, vanaf omni-kategorieë na patos-kategorieë voorgestel. Dit word beredeneer dat ' $n$ teopasgitiese teologie 'n belangrike bydrae kan lewer om statiese Godskonsepte, wat grootliks vanuit die Romeinse en Griekse denkwêreld gekom het, in die rigting van 'n meer dinamiese Godsverstaan te skuif. Die gedagte van die 'volhoubaarheid van God' word aan 'n nuwe verstaan van die medelye van God (ta splanchna) verbind. Vandaar die voorstel vir 'n paradigmaskuif vanaf almag en alwetendheid na 'n patosvolle, infinitiewe omgee-identifikasie (die pneumatologiese volhoubaarheid van daar-wees-vir).

Within the social processes of transformation, the connection between oppressive structures, radical political change and the reconstruction of the society, the connection between power issues and the quest for human dignity and justice, surfaces anew. The abuse of power (threat power) puts a lot of pressure on interventions that aim at compassionate reconciliation, rather than instant solutions and rational explanations for contradictory events within social processes of change and severe forms of suffering.

The quality of the pastoral ministry is often challenged by unexpected events of suffering and unexplainable disasters. The latter raises the theodicy question, namely how to deal with the connection between the power of God (God Almighty) in the face of the so-called undeserved fate that seems to contradict the love of God and that robs human beings from all forms of meaning and hope. In the attempt to comfort people, caregivers are challenged by the question 'why?' within the reality of painful, existential paradoxes. Or should the art of comfort and compassionate caring be rendered as in appropriate for our time? Or should it perhaps been phased out as one of the 'zombie categories' of Christian spirituality?

In his book, Reconstructing practical theology, Reader (2008:1) points out the danger of 'zombie categories' (Ulrich Beck quoted in Reader), namely the continued employment of concepts that no longer do justice to the world we experience, and yet, which are difficult to abandon because of tradition and because they are not yet very redundant. Zombie categories are therefore described 
as the 'living dead', the tried and familiar frameworks of interpretation that have served us well for many years and continue to haunt our thoughts and analyses, even though they are embedded in a world that is passing away before our eyes.

What then is meant by the intervention of God in compassionate caregiving, and the pastoral challenge to reintroduce the God-question in comfort when one faces the fact that life is indeed unusual and framed by unpredictable happenstances?

\section{The 'Black swan' metaphor}

As argued in The Black swan (Taleb 2010), life cannot be explained in terms of deterministic explanations within a cause-and-effect schema of interpretation; 'things developed through contradiction (or opposites) in a way that elevated mankind into higher forms of society' (2010:13). Transferred into doing practical theology, the implication is that the intervention of God and the understanding of divine presence in life events, supersede rational explanation - 'the pathology of thinking that the world in which we live is more understandable, more explainable, and therefore more predictable than it actually is' (2010:9).

Within the framework of the research topic, namely the God-question in a pastoral theology of compassion, one can expect that compassion in itself is in essence not a positivistic category of rational explication, but of existential beingwith, within the discrepancies of life. The God-question should thus be posed within the fact of paradox as a highly 'improbability' rather than an explanatory cause. God is like a kind of 'Black swan', not like a purely anthropomorphic entity that the Greeks called 'deus'. God operates in categories that point to the improbable. Taleb (2010) states:

Critically the Jewish god did not lend himself to symbolic representation. Likewise, what many people commoditize and label as 'unknown', 'improbable', or 'uncertain' is not the same thing to me; it is not a concrete and precise category of knowledge, a nerdified field, but its opposite; it is the lack (and limitation) of knowledge. (p. xxix)

Black swan terminology implies to think in terms of incompleteness, complification, paradox, improbability and unpredictability. 'Black Swans being unpredictable, we need to adjust to their existence (rather than naïvely try to predict them)' (Taleb 2010:xxv); human blindness with respect to randomness (2010:xxiii). Meaning and the connection to suffering and the unexpected, surface at the interface and liminality of the improbable friction between divine presence and human surprise. In this respect one should start to render compassion and power in terms of Black swan terminology as categories of 'the unusual' (2010:xxviii).

With reference to methodology, one could assume that rather than the methodology of metaphysical and hierarchical thinking (top-down) and the methodology of phenomenological and experiential, observational thinking (bottom-up), Black swan thinking is about zigzag thinking. It is circular and spiral due to unpredictability and paradox. Thus, this is the reason why empathetic and sympathetic understanding in compassion thinking gain from chaotic disorder, rather than from logic order - it is the challenge to deal with the unknown (Taleb 2012:4).

In her book, Country of my skull, Krog (1998) struggles with the meaning question, power issues and the future of South Africa after the 'truth and reconciliation'. It seems as if core issues like reconciliation, sharing, fair distribution and empathetic acknowledgement of the wrongs of the past in the attempt to heal the painful scars of the past, are hampered by new power struggles and a lack of compassion - chaos is emerging on the horizon of the so-called 'Rainbow Nation' of Desmond Tutu. Krog poses the burning question of the improbable: 'If the Commission can't make it work, what hope does the country have?' (1998:276).

Former Archbishop Desmond Tutu (2004) sums up the current predicament of South Africa as follows:

We were involved in the struggle because we believed we would evolve a new kind of society. A caring compassionate society. At the moment many, too many, of our people live in gruelling demeaning, dehumanising poverty. We are sitting on a powder keg. We really must work like mad to eradicate poverty. (p. 33)

Thus, the challenging question for a pastoral theology and practical theology that claims to be contextually relevant is the following: How should we reflect on the connection, even disconnection, between power, and the engagement of the pastoral ministry within the plight of suffering human beings for meaning and human dignity? What is meant by compassion when the caring ministry connects the undeserved suffering of human beings, and the chaotic abuse of power to the theological notion of the 'power of God' and the compassion of God's kenotic love?

\section{Top-down suppression and the reframing of God-images}

The quest for theological clarity on what is meant by compassion in pastoral theology is vibrant within different contextual discourses in practical theology. The quest for clarity and compassionate understanding surfaces within many burning social and political issues. For example the gender discourse deals with the suppression of women due to the ideology of patriarchalism and male chauvinism. There is an urgent need for a hermeneutical deconstruction of power issues, framed by a top-down approach of hierarchical and patriarchal thinking.

Feminist theology is inter alia about the deconstruction of fixed and stigmatised, discriminating categories; it criticises the power relations amongst people and the hampering factor of male domination (threat power) based on theological justification (Bons-Storm 1996:25). Therefore, feminist theology as a whole, and feminist pastoral theology 
within it, oscillates between the two poles of critique and reconstruction (Moore 2002:12-13). In the book, Feminist theology, edited by Susan Frank Parsons, Rosemary Ruther (2002:3) reiterates the basic assumption that feminism is a critical stance that challenges the patriarchal gender paradigm that associates males with human characteristics defined as superior and dominant (rational power), and females with those defined as inferior and auxiliary (intuition, passivity).

With reference to the debate on the God-question in practical, life issues, McFague (1987) argues that the motherly and compassionate acting qualities of God should be emphasised, namely the world as the body of God (1987:69-78).

The important volume on the meaning of doing practical theology within different cultural contexts and concrete life issues, reiterates the reinterpretation of the God-factor in theory formation for practical theology (Miller-McLemore 2012:2-20). The shift in practical theology is away from religious meaning 'beyond the everyday' to religious meaning 'in the mundane' (2012:7). In this regard, the reframing of God-images in practical theological reflection on life issues becomes imperative. In practical theology, God should be portrayed more in terms of compassionate, active verbs, than in substantial, powerful nouns.

Old Testament studies assert that the Jewish and Christian God is more verb- than noun-like. According to MillerMcLemore (2012):

Several biblical scholars translate God's answer to Moses' request for God's name in Exodus 3; 14, YHWH, as 'I am who I am becoming' rather than the etymology of $\mathrm{YHWH}$, 'I am who I am'. (p. 8)

The point is, in either case, YHWH is a 'verbal form' ${ }^{1}$ and indicates the sustainable presence of an ongoing intervention and promise of God's faithful and covenantal being-with, rather than a metaphysical entity interpreted in terms of immutable categories.

Despite the claim that secularisation makes the God-question in processes of urbanisation irrelevant (Cox 1965), it is still vibrant in many of the so-called secularised societies. In her book, Seelsorge, Doris Nauer (2010:70) puts the question of the credibility and reliability of soul care (glaubwürdige Seelsorge) a new on the academic agenda of theological education, as well as on the calendar of caregiving and the appropriateness of communities of faith. A credible, reliable and sustainable understanding of pastoral caregiving is possible only with the emphasis on quality (2010:105-109) and the understanding of the Christian tradition of wisdom with its emphasis on compassion, faith and God.

The challenge to reopen the debate on compassionate rather than powerful omni-categories is not new. Hall (1993) already

\footnotetext{
1.In English, "gerunds are words that end with -ing and look like verbs but function as nouns. That is, they are nouns (words that name persons, places, ideas, etc.) that contain action; they are verbs used as nouns' (Miller-McLemore 2012:8).
}

warned against the overemphasis on power categories that portray God as an imperialistic father almighty that represents more a Caesar-like emperor ${ }^{2}$ than a compassionate being-with.

The 'Father Almighty' developed under the influence of an affluent society into the romantic sentimentality of Father Christmas all-merciful. Instead of a suffering God the omnipotent God was proclaimed. One can say that due to imperialistic undertones the triumphalism of a theology of glory 'removed the cross from the heart of God' (Hall 1993:96). Hall (1993) claims:

God is depicted as one who, unlike us, does not exist under the threat of nonbeing in any of its manifestations. Thus, the divine power (omnipotence) is not challenged by any lack or weakness; the divine knowledge (omniscience) is not circumscribed by ignorance, uncertainty, or inherent limitation; the divine presence (omnipresence) is not subject to the constraints of time and space; and God is not vulnerable to change or prey to passions that may be aroused by any existential eventuality (immutability). (pp. 96-97)

Our common use of power takes political power as its exemplar; power as domination. The perfection or fulfilment of power as domination easily becomes manifest as 'absolute power', 'the tyrannical enslavement or eradication of whatever opposes such power' (Pasewark 1993:3).

What then are the theological implications for compassionate thinking in pastoral caregiving? Is it possible to shift the emphasis in practical theological reflection from the more traditional omni-categories of imperialistic Godimages to the more compassionate categories of pathos thinking in theopaschitic theology? Furthermore, is it possible that Christian theological reflection on the power of 'God Almighty' was more informed by an imperialistic interpretation of the power of God (the threat image of pantokrator-images) than by the compassionate interpretation of a weak, suffering God (theopaschitic images of weak, vulnerable power)?

\section{Compassionate thinking and the improbability of kenotic love}

Compassionate thinking puts a huge burden on human selfunderstanding. Davies (2001:xx) formulates this challenge as follows: 'If compassion is knowingly to put oneself at the risk for the sake of the other, then self-dispossessive virtue is predicated upon a prior state of self-possession'. If translated into theological language one should link compassion to the ethos of self-sacrifice and the discovery that in Jesus Christ, as the 'compassion of God' (cf. Lk 1:78), God has already preceded us. According to Davies, in compassion being is affirmed through the Other in faith and hope: '... divine self-emptying and self-dispossession for the sake of creation' (ibid:xx).

2.W.N. Pittinger (quoted in Hall 1993:54) argued that the typical picture of divine
omnipotence is a case of 'giving to God that which belongs exclusively to Caesar'. omnipotence is a case of 'giving to God that which belongs exclusively to Caesar
Even the love of God became a masculine affair supported by patriarchalism. 
Davies (2001:21) further argues that in compassionate thinking the essence of compassion is contracted by the principle of self-denying or kenotic love (a dispossessive and decentred model of the self). Compassion operates on the basis of selfemptying for the sake of the other. It contains a rational component based on altruistic ethics (the cognitive structure of compassion); an emotional component based on an attitude of empathy (the affective component of compassion); a volitional component based on the intentionality to be open for the other or the Other (the conative component of compassion); as well as a spiritual component based on the encounter with the kenotic love of Christ - the compassion of God (the theological and divine or transcendent component of compassion). The latter constitutes the meta-physical horizon of openness and transcending hope.

Within the Hebrew tradition the scriptural narrative as displayed in Exodus 3:14 founds the priority of compassion, namely the act of 'divine presencing which is a boundless and unending being-with' (Davies 2001:20). The notion 'I am who I am' is one of the most profound statements regarding the being and essence of God. The Hebrew tradition refers to a fundamental promise and expression of the faithfulness of God. In fact, it can be translated and paraphrased that God is a unique kind of deity, namely that God will always be there where his people are. Exodus 3:14 can thus be viewed as the foundation of a spirituality of hope and a theological understanding of the spirit of compassion as instigated by the compassionate being of God with the suffering predicament of his people.

\section{Basic assumption}

My basic assumption is that within the theodicy question and the human quest for meaning in suffering, theology is often a captive of a metaphysical framework of interpretation, thus the affinity for static omni-categories. For example in the first 400 years after the establishment of Christian texts on the Christ-event, cultural and philosophical categories were borrowed from Greek philosophy and Hellenistic thinking (logos-terminology) in order to explain the reality or being of God. Metaphysical categories were often applied to explain God's existence in terms of ontological thinking. Categories like the omnipotence, omniscience, immutability and impassibility dominated the scenario of dogmatic and confessional thinking. ${ }^{3}$ Largely, this was the reason for the very controversial theological debate in the previous century regarding the so-called 'death of God debate' (Altizer \& Hamilton 1966).

\footnotetext{
3.The unarticulated intention was in many church synods to 'save' God's power within the framework of a kind of ecclesiastic imperialism and cultural obsession fo control. The Confession of Faith (Belgic Confession 1959) starts, for example with the notion of power as the creation, preservation and government of the universe. God as Father 'watches over us with paternal care, keeping all creatures so unde his power that not a hair of our head (for they are all numbered), nor a sparrow can fall to the ground without the will of our Father ... ('and not one of them falls apart from your Father's will'). Although 'will' is not mentioned in the Greek text (Mt from your Father's will'). Although 'will is not mentioned in the Greek text (M 10:29; literally: without our Father), the interpreters read 'will of the Father' into the text. In the background of the religious mind, God determines everything in cause-and-effect manner so that the will of God should at least equal divine power. Divine power is then interpreted in terms of cause (first principle) and governance (strength) and not in terms of care and compassion (vulnerability). The quest fo meaning in suffering is then dominated and demarcated by categories of contro and expansion.
}

Within the framework of compassionate thinking, what is the implication for pastoral theology, very specifically for the understanding of the 'power of God' in acts of pastoral intervention and caregiving, as well as for the hermeneutics of a 'suffering God' in practical theology?

\section{The theological dilemma in theistic thinking: From static categories into dynamic thinking}

According to Küng (1970), orthodox thinking in dogmatism is characterised by the cause-effect categories of deterministic thinking and the static categories of theism. The challenge in theology is therefore to move from static categories into the dynamics of pathos categories. ${ }^{4}$ This debate is still vivid in the reflection on the question regarding the link between the God-factor and the quest for action in practical theological thinking (fides quaerens actum).

In a keynote address of the meeting of the International Academy of Practical Theology (IAPT) in 2015 in Pretoria, the systematic theologian J.W. van Huyssteen (2015) proposed a 'bottom up approach' wherein postfoundationalism ${ }^{5}$ wants to brake with static metaphysical thinking in favour of a more observational and empirical approach and inductive rationale for the action of belief. This approach is supported by J. Müller (2011) in his argument for a postfoundational approach in theory formation for practical theology.

In foundationalism, ontological categories from philosophy were often borrowed to aid theology in its attempt to define theological truths. This is the reason why John A.T. Robinson, in his controversial publication, Honest to God (1963), exposed 'traditional theism' (defining of God in abstract, static and metaphysical categories) to its undergirding static paradigms. His intention was inter alia to turn theological reflection away from a metaphysical paradigm to the reality of our being human within the realm of suffering. Instead of the abuse of God as a deus ex machina, Christian spirituality should be directed by the powerlessness of a suffering God (Robinson 1963:39). God is not like a Grandfather in heaven, a kindly Old Man who could be pushed into one corner whilst we get on with the business of life (1963:41). 'God, the unconditional, is to be found only in, with and under the conditional relationships of this life: for he is their depth and ultimate significance' (1963:60).

4.In Menschwerdung Gottes, Küng (1970:660-631) pays particular attention to this question. He sees this as a challenge to dogmatic orthodoxy. The incarnation already challenges the concept of an apathetic God. Küng therefore bases his theory of the suffering God on the incarnation which involves a dynamic Selbstentäusserung (selfcondescension; self-abandonment) of the Logos. The latter must not be interpreted as an apotheosis of the flesh, but as an ensarkosis of the Logos: God is not 'static', but 'pathetic' in the events surrounding the incarnation. Küng views God's suffering because of the fact that the God-Logos, as subject of the incarnation, is also intimately involved in the Son's suffering. We can thus speak of the death and suffering of the God-Logos.

5.Cf. Van Huyssteen (1997). In general, postfoundationalism can be rendered as an epistemology denoting a rejection of an assumed or given authority (top-down approach) or causative principle. The rationale for the action of belief is embedded and determined by contextuality and the constructs of cultural settings. See also the connection between postfoundationalism and theoryformation in practical theology (Müller 2011). 
Robinson's attempt can be linked to Paul Tillich's ontology of acceptance and his use of existential categories. Tillich (1965:44) thus, argues: 'Nevertheless it is necessary for an ontology of courage to include an ontology of anxiety.' Being should be founded by an external factor that functions as the ground of being, namely divine Being (divine acceptance): 'Despair is an ultimate or "boundary-line" situation. One cannot go beyond it' (1965:59). God is then introduced as the metaground of all being and the source of self-affirmation, self-acceptance and courage to be (1965:152-183).

The more a culture is forced to think in terms of efficiency, the more pressure is placed on existing categories to revisit frameworks of interpretation. This was for example the case in the surfacing of 'process theology'. ${ }^{6}$ Process theology is a type of theology that was developed from Alfred North Whitehead's (1861-1947) process philosophy, and most notably developed by Charles Hartshorne (1897-2000) and John B. Cobb (b. 1925). For both Whitehead and Hartshorne, it is an essential attribute of God to affect and be affected by temporal processes, contrary to the forms of theism that hold God to be in all respects non-temporal (eternal), unchanging (immutable), and unaffected by the world (impassible). Process theology does not deny that God is in some respects eternal (will never die), immutable (in the sense that God is unchangingly good), and impassible (in the sense that God's eternal aspect is unaffected by actuality), but it contradicts the classical view by insisting that God is in some respects temporal, mutable, and passible.

The undergirding assumption surfaces, namely that static categories within a fixed metaphysical framework are not any more appropriate to meet questions regarding the intervention of God within transformative life events. In the sixties, Harvey Cox (1965) pointed out that the so-called 'death of God' is not merely an intellectual death, but an attempt to probe into static categories in order to deal with the dynamics of the 'secular city'. It is also intuitive and aesthetic (Cox 1969:28). According to Cox (1969:28), if we really want to 'experience' and 'encounter' God, we have to meet him first in the dance before we can define him in the doctrine.

A good example of attempts in the previous century to move from static categories into more dynamic categories is Eberhard Jüngel's (1967) systematic reflection in his dissertation, Gottes Sein ist im Werden. God's being is interpreted as an event of becoming. It means that God's revelation of himself is not complete. This does not imply that God himself is incomplete, but rather that God reveals himself as a Für-sich-sein [a Being-unto-himself] who, in his grace, is also a Für-uns-sein (a Being-with-and-for-us). In his capacity as a Being for us, God discloses himself as being involved in the suffering of humankind, and thus he becomes

6. Process theology and process philosophy are collectively referred to as 'process thought' Process the procy is the philosophical and the chang . Process theology is the philosophical and theol changing, as is the univers. Therefore our knowledge of God must be progressin as we learn more about $\mathrm{Him}$, and it can never rest in any absolutes, which is why process theologians deny the absolutes of God's immutability and truth. (cf. http:// en.wikipedia.org/wiki/Process_theology) a suffering God for suffering human beings in a dynamic act of revelation. In these events of God-being-for-us, God's mode of being is still in the process of becoming (incomplete); it is a kind of infinitive (continuous happenstance).

The happenstances of life are embedded in sociocultural processes and events of transformation and unexpected change. The intriguing question for theology is how the God-question should meet challenges posed by phenomena that seem to make pastoral interventions superfluous and ineffective.

\section{From secularisation into apatheism and anatheism}

Secularisation has been predicted to swamp religious belief. In his remarkable book, A history of the modern world, Johnson (1985:698) writes that history has an illogical factor: the unpredicted. It seems that now that we enter a new century, even the term secularisation is in disrepute. New forms of spirituality are emerging. Johnson (1985) points out:

While theologians at the universities of Tübingen and Utrecht were diminishing the total of Christian belief, strange charismatics in the slums of Mexico City and Sao Paulo, of Recife and Rio, of Cape Town, Johannesburg, Lagos and Nairobi, were adding to it. The first group spoke for thousands; the second for scores of millions ... (p. 707)

According to Ara Norenzayan, a psychologist at the University of British Columbia in Vancouver, Canada, there are places where secularisation is making huge inroads: western and northern Europe, Canada, Australia, Japan and China (quoted in Lawston 2014:31). Norenzayan (2014) further states:

Even in the US - a deeply Christian country - the number of people expressing 'no religious affiliation' has risen from 5 per cent in 1972 to 20 per cent today; among people under thirty, that number is closer to a third. (p. 31)

Lawston (2014:31-32) refers to Phil Zuckerman, a socialist at Pitzer College in Claremont, California, who remarked that although it seemed as if religious interests were back at the turn of the 21st century, secularisation is also back in business. Recent developments in the prosperity cult are contributing to precipitous decline in many societies all over the globe. Religion is withering across the board. Despite pockets of increased fundamentalism and charismatic upheavals, religion is no longer a meaningful alternative to threats of violence, fraud, and severe poverty.

It was always argued that religion is the moral glue that holds society together, and if you get rid of it, everything collapses. According to research in sociology, the evidence, however, suggests otherwise. It seems that the more secular a country or a state, the better it does. More and more sociologists are debunking the notion that religion is necessary for a healthy society. The argument surfaces that secularisation can lead to social improvements. Says Zuckerman (quoted in Lawston 2014): 
First, if you believe that this is the only world and there is no afterlife, that's going to motivate you to make it as good a place as possible. Number two is the emphasis on science, education and rational problem solving that seems to come with the secular orientation - for example, are we going to pray to end crime in our city or are we going to look at the root causes? (p. 35)

With reference to Norenzayan (quoted in Lawston 2014:33), there is a new kind of atheism ${ }^{7}$ that is surfacing in affluent societies, namely an irreligiosity that is very apathetic. Wealthy people do not really care about issues regarding the transcendent realm of life. With apatheism is meant: 'This is not so much doubting or being sceptical, but more about not caring.' Apatheists simply do not think about religion. In apatheism you just bypass religion within a nonchalant cool attitude of carelessness. Religion and hope flourishes in societies where there is a lack of general health care, widespread job insecurity and a poor safety net.

It seems that there is indeed a case for arguing that homo sapiens is also homo religiosus (Armstrong 1997:3). At the same time one cannot ignore the fact that statistics in religious countries point in the direction of the gradual decline of religious spirituality. On the other hand, there are new voices in research on the philosophy of religion. For example Richard Kearney in his book, Anatheism: Returning to God after God (2011), draws heavily on Paul Ricoeur's model of translation or 'linguistic hospitality' and his quest to enact and to inhabit the Word or word of the Other or other. Spirituality should return to the dimension of the sacred in religious texts: the mystical or apothatic that appears in religious and wisdom thinking. Burkey (2010 - in his book review of Kearney) states:

Out of the depths of the abyss a return and recovery of the sacred is possible, a re-birth - not of the God of omnipotence but a God of service and a sacramental 'yes' to life. Maybe. God-may-be, again, anew. That is the eschatological wager of anatheism. (p. 162)

The anatheistic option of Kearney should indeed be explored by Christian wisdom thinking. It is true that the traditional understanding of the sacred as a religious category should never ignore the fact that transcendence cannot be reduced to merely intramundane categories and the realm of the saeculum. As Kearney (2011:152) argues: 'The sacred is in the world, but not of the world.'

Between the abstract metaphysical interpretation of theism and the irreligiosity of apatheism and atheism, anatheism is seen as an attempt to rediscover the sacred beauty of life. Instead of the otherworldly traditional Omni-God, and above the rather abstract and well-worn master concept of Postmodernism, Kearney reintroduces the interplay between the spirituality of hospitality and the dubious figure of the Stranger or stranger. For him the metaphor of

7.In CREDulous atheism, That does not mean incredulous as in unbelieving, but as in not being exposed to CREDs, those dramatic displays of faith' (Lawston 2014:33) Religion combined with power has a kind of spellbound effect on people. In fanatic Religion combined with power has a kind of spellbound effect on people. In fanatic
manifestations of belief, people are willing to die for their faith. Those beliefs manifestations of belief, people are willing to die for their faith. Those beliefs
become more contagious. When people don't see extravagant displays of faith, then there is some evidence that this leads to decline of religion. the 'stranger' rekindles an awareness of the sacred in the sense that the concept embodies something else, something more, something other than what the self can contain or grasp (Kearney 2011:152). 'The anatheistic wager concerns how we respond to this surplus, this transcendence within immanence, this glimmer of the infinite in the finite' (Burkey 2010:163).

Simon Critchley (2012:18) refers to the 'faith of the faithless'. This paradox can be connected to the need for new forms of self-realisation and the quest for 'more aesthetic fidelity' (Oscar Wilde quoted in 2012:3). Critchley (2012) says:

At the core of Wild's remark is the seemingly contradictory idea of the faith of the faithless and the belief of unbelievers, a faith which does not give up on the idea of truth, but transfigures its meaning. (p. 3)

In our search for sacred spaces of truth and spiritual places of meaning in our current network culture (Barnard, Cilliers \& Wepener 2014:1-2) one has to face the dynamics of liminality - the position of 'betwixt and between'. Nothing is fixed between apatheism and anatheism, and theology has to revisit its own sacred sources with the awareness of a bricolage attitude, namely to tinker with fixed beliefs by 'cutting and pasting' from different cultures, religions, beliefs and philosophies (2014:120). Even the articulation of the meaning of the divine in different cultural settings makes the naming of God a liminal issue - 'always moving, and not captured in "freeze-frame"' (2014:2).

How should we then interpret the God-question; very specifically the notion of the power of God (omnipotence) within social and cultural changes?

\section{The stumbling block of imperialistic omni-categories}

Within the history of Christian doctrine, several schemata of interpretation (Louw 2000:5-6) in a pastoral hermeneutics (Capps 1984) can be identified:

- The Hellenistic schema: In this model, God is interpreted in terms of a causal and logical principle. As the cause of all things and events, God is viewed in terms of immutability and apathy. Suffering does not affect God at all: God's immutability and the principle of causality. ${ }^{8}$

- The metaphysical schema: God's transcendence is understood as being remote from historical events. Essentially, revelation implies God's concealment. Behind revelation 'another God' exists. The otherness of God therefore introduces an ontological schism between God and our human existence: God's transcendence - God as ultimate Being.

- The imperialistic schema: According to the Constantine paradigm, God's kingdom should be understood in terms of militant power. God reigns as a Caesar and determines every sphere of life. Ever since, it has been a real danger

8.Inbody (1997:139): "The notion of God as the "unmoved mover" is derived from Aristotle, at least so far as Western thought is concerned.' 
to fashion God in the image of the 'cultural gods' - the imperial rulers of the Egyptian, Persian and Roman empires. The church gave to God the attributes which belonged to Caesar (cf. also Inbody 1997:139). The church becomes a cultural institution with God as the official Head of a powerful establishment: God's omnipotence God as Pantokrator. ${ }^{9}$

- The patriarchal schema: God acts as a great Patriarch and dominates human beings. Therefore God's actions in suffering are regarded in terms of purification or edification and retribution. As Patriarch, human beings face a very stem God: God as an authoritarian Father.

- The hierarchical schema: Life is viewed as an ordered system. At stake are position and differentiation. The latter is structured in terms of importance, status and position along the lines of class differences. In such a model, the tension between superiority and inferiority determines people's understanding of God: God as royal King, Lord and ruling Judge.

- The economic and materialistic schema of wealth, achievement, development and affluence: God becomes an official and public idol: a God who safeguards prosperity. He is then hijacked to serve our selfish needs. Belief becomes a religion - it is misused as a good investment to bypass tragedy. The kingdom of God becomes a stock exchange: God as Director and Manager, Provider of wealth and prosperity.

- The political and societal schema: Due to the role of liberation theology, God becomes a liberating God who sides with the oppressed, takes care of the underdog as well as those discriminated against. The kingdom of God is then interpreted in terms of the exodus theme and our human dream for freedom and endeavour for justice by means of violent intervention: God, the Liberator and 'Freedom Fighter'.

Behind all these schemata lurks the more fundamental and primary question concerning the significance and meaning of our human endeavour. What is the purpose of life? Although we are all facing the dawn of the 21st century, one is conscious of a vast and even palpable dissatisfaction permeating the status quo - a disenchantment. 'Perhaps little overt theological discourse takes place outside the churches, synagogues, mosques and academic religious circles, but there is much covert searching after ... something. Mystery? Transcendence? Meaning?' (Hall 1993:132).

It becomes clear that the link between God and the misery of our being human functions in some way or other as a sort of proof for God's reliability and faithfulness. A God who is viewed in terms of apathy and who does not understand suffering creates a 'non-pastoral' impression: God does not really care. Because of the possible danger of 'the apathy of God' (immutability) in pastoral ministry particularly, the

9.Power, even the power of God, is mostly defined as domination and contro (Pasewark 1993:2). This understanding of power always presents the need to (Pasewark 1993:2). This understanding of power always presents the need to
defend the notion of God's omnipotence on philosophical and theological grounds and for reasons of religious life. pastor becomes aware of the fact that suffering radicalises the quest for God. ${ }^{10}$

Inbody (1997:140) captures this problem very aptly when he argues that, in our attempt to rethink the meaning of divine power, two things can happen. Our God-image can become 'too small' or 'too big'. If God can only empathise with the suffering of the world, but can do nothing about it, God is too small. If God is identified with nature, and can do nothing more than what positivists mean by natural law, God is too small. If God is identified with human capacities, abilities, creativity or human ideals, then God is minimalised. On the other hand, if God is identified with omnipotent power, as the kind of power that, because of definition, can do 'just anything', God is too big. When a theistic notion of divine omnipotence portrays God's kingdom in terms of an empire, he becomes too militant and strong. God is then merely a Hellenistic pantokrator.

The Hellenistic and Roman background of many depictions of God should be acknowledged (Nyssen 1982:413). It is quite understandable that in their search for identity, the followers of Christ in the Roman era expressed their identities in terms and images that draw on widely shared cultural categories. The similarities are evident. However, Christians indeed reinterpreted such categories in a different and unique way. According to Harland (2009:47), the letters of Ignatius of Antioch, which reflect group life in two central hubs of early Christianity - Western Asia Minor and Syrian Antioch - provide a case in point. In these writings Ignatius drew heavily on categories from the culture of Greco-Roman cities in order to build up the identity of the Christian communities. The same process is evident in imaging. For an example see Figure 1 ('Mosaic with image of Apollo, from Greek mythology').

It should be mentioned here that Byzantium art cannot be separated from the historical background when basileia ton Rhomaion was transformed to Byzantium and its Greek roots (Evans 2004:15). In 1557 the name of the empire was replaced with the term Byzantium. Constantinople was seen as the place for the restoration of political and religious power (2004:5).

What should be reckoned with is that during the Byzantium period, many images of Christ represent a wedding of the pagan icon genre ${ }^{11}$ with Roman secular portraiture. ${ }^{12}$ Mathews (1998:51) refers to the case of Bishop Gennadios of Constantinople (AD 458-457) and a painter, who dared to paint the saviour in the likeness of Zeus. The story goes

10.CF. C.F. Krause, Leiden Gottes - Leiden des Menschen (1980:7), for his discussion on the radicalising effect of the God-suffering theme: 'Denn mit dem Thema "Gott und das Leiden" steht heute nicht nur das Verständnis der menschlichen Leidensgeschichte sondem auch - und zwar in theologiegeschichtlich bisher ungewöhnlicher Zuspitzung - das Gottesverständnis selbst zur Diskussion.'

11.Velmans (2007:20) points out the influence of Greek thinking on the idealism of the early church fathers; very specifically the impact of Pseudo-Dionysius Areopagita (ad 5).

12. Many of the pagan images were Christianised in order to serve a different purpose. See for example Zakssaya (2006:50): On a statue of Dionysus was written just above the genitals Psalm 28:3 (ad 8-9). 

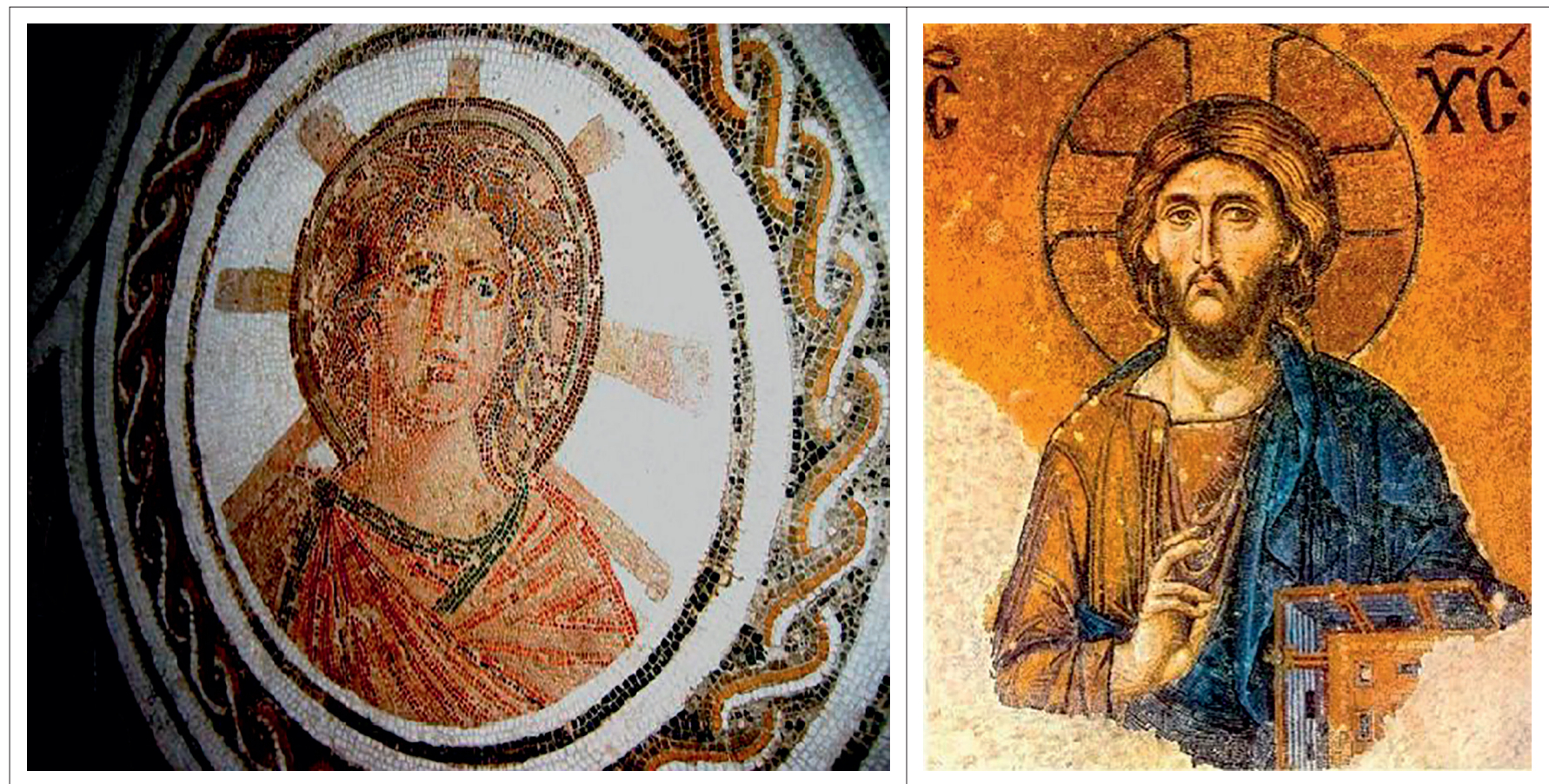

Source: Hagiasophia-christ.jpg. Public domain

The depiction of Christ pantokrator with halo and Hagia Sophia shows a remarkable resemblance.

FIGURE 1: Mosaic with image of Apollo, from Greek mythology.

that he found his hand withered. The bishop healed him and instructed that Christ must have shorter, frizzy hair. However, in the later development of icons, the Zeus type won, because within the framework of the power issues ${ }^{13}$ in Byzantium culture, the Zeus depiction was more forceful (1998:51). ${ }^{14}$ The great male gods of antiquity - Asklepios, Serapis and even Suchos - 'all assumed the broad forehead, long hair, and full beard that characterized Zeus, the father of the gods. Christ should hardly be seen as less powerful than they' (1998:51). ${ }^{15}$ In this regard, the blessing Christ from the monastery of St. Catherine on Mount Sinai should be rendered as a perfect example: 'All the verist tricks of Roman portraiture are added to convey the powerful presence of Christ' (1998:51) (cf. Figure 2: 'The blessing Christ').

One can understand that iconography in the early Christian church cannot be understood without taking the Roman cultural background into consideration. Icons portraying the Christian understanding of the Divine were interlarded with notions of power and empire. ${ }^{16}$

13.For the further impact of power images in Byzantium icons, see the research of Helen Evans (2004:5-16).

14.Early Christian art is permeated with symbolism. See in this regard the very early testimony of Eusebius concerning Orpheus as symbol of Christ, even Heracles. All act as bearers of the idea of salvation, of the victory of good over evil, of prosperity and well-being (Zakssaya 2006:49).

15.Christian's claims of historical authenticity for the icons are founded on faith more than fact. Icons in Christian traditions should therefore not be interpreted from the viewpoint of historical fact, but from the viewpoint of spiritual experiences and faithful imaging. Byzantium art was indeed an attempt to portray Christ as superhuman, thus the reason for depictions larger than life scale (Mathews 1998:51-52).

16.One should bear in mind that iconography in the Christian tradition was greatly influenced by the Roman culture of the period ad 200-400. Gombrich (2006) tells: The Romans were a matter-of-fact people, and cared less for fancy goods. Yet their

\section{The theory of the 'Emporor mystique' in iconography}

It is becoming clear that the process of imaging God in early Christianity is indeed very complex. We were not there and cultural contexts and their impact and influence on imaging can be very subtle indeed. When adopting a hermeneutical approach to understand the cultural impact on God images, one should therefore be very careful how one goes about understanding imaging in the Christian faith tradition. One theory in the interpretation of early iconography is called the theory of the 'Emperor mystique' (Mathews 1993).

The 'Emperor mystique' approach refers to the theory in iconography accepted by art historians, namely that the images of Christ in early Christian imagery were derived from images of the Roman emperor. Mathews (1993) puts it this way:

Both the shape and the power of the images, according to this theory, come from reliance on imagery formerly used to present the emperor. It is a 'mystique' as far as it involves a reverence bordering on cult for everything belonging to the emperor. To such historians dropping the word 'imperial' into a discussion represents an appeal to a kind of ultimate value beyond which one never looks. (p. 2)

pictorial methods of telling the deeds of the hero proved of great value to the religious which came into contact with their far-flung empire (p. 96). Gabriele Kopp-Schmidt (2004:68-69) points out in her book, Ikonographie und Iconologie, that it was during the 4th century ad that the Christianisation of Roman culture occurred. The Romans made use of examples from ancient Rome in their depiction of Christ and in their church architecture. Constantine and his family supported the 'new movement'. When Christianity became a state religion at the end of the fourth century ad, elements of the Caesar cult were accommodated in the liturgy and priesthood. In order to gain power, it was importan 

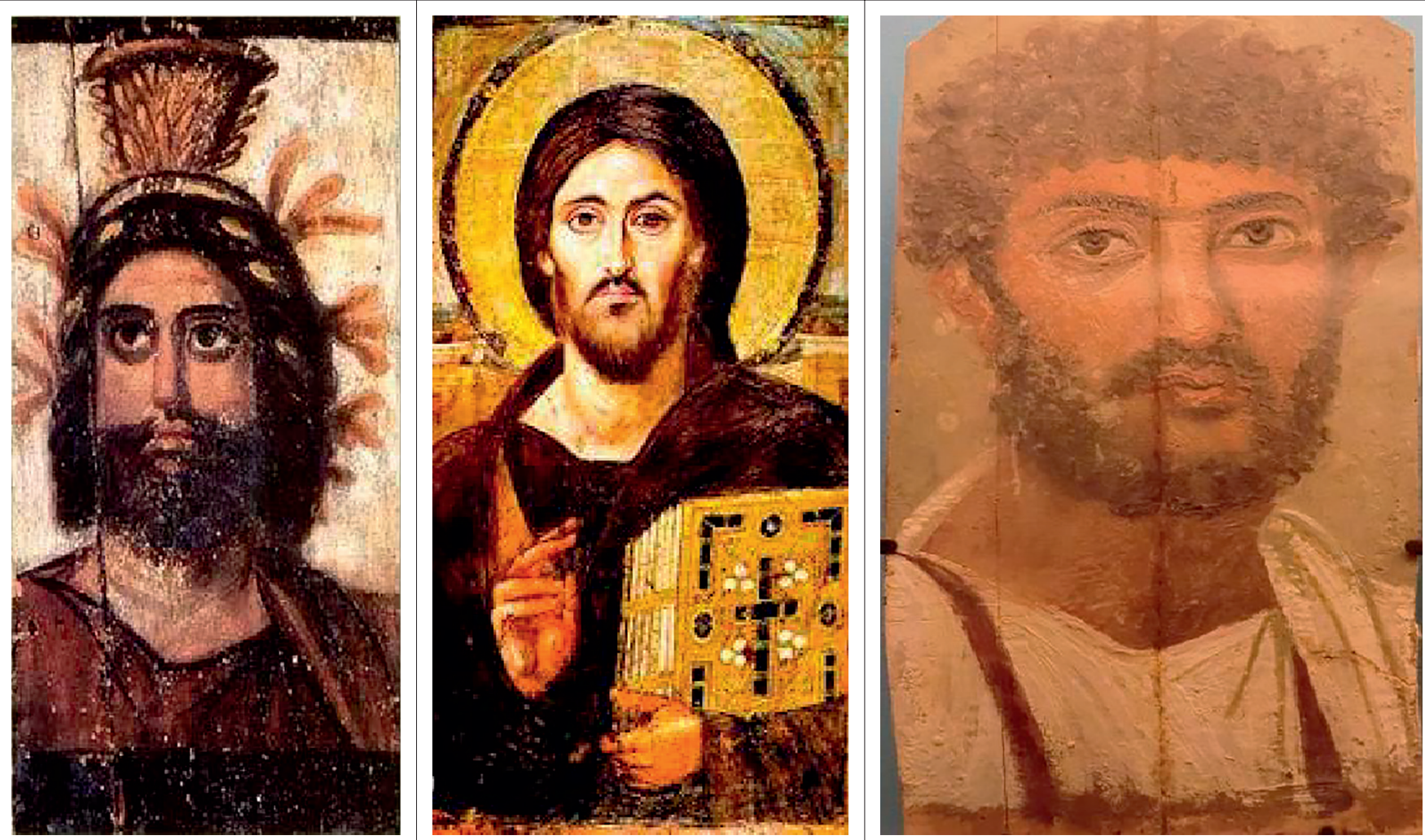

Source: Free image: accessed 08 January 2013, from http://en.wikipedia.org/wiki/Christ_Pantocrator

The attempt to guard against pagan influences was predominant in the history of Christianity. It even led to theories that there is a close connection between the Isis cult and the development of private home altars (Weitzman 1982:5). It was believed that Serapis, with his shrine situated in Alexandria, united in himself the underworld powers of Osiris with the healing powers of Asclepius. His head was given the broad brow and copious hair of Jupiter. He wore a wreath of laurel and balanced a grain measure on his head. In AD 400, an association between Serapis and Zeus developed (Mathews 1993:184-185). The possible similarity between the depiction of Serapis (a Greco-Egyptian god BC: left panel) and the oldest icon of Christ Pantokrator on a panel (right) from the Saint Catherine Monastery near Mount Sinai, was obvious to many. The two different facial expressions on either side may emphasise Christ's two natures as fully God and fully human. Middle: Mummy portraits were sometimes placed on mummies instead of actual mummy musk. The picture of the young man is in tempera, that is colour mixed with egg, circa AD 110 (Permission: Nationa Museum Copenhagen. Photo: D.J. Louw). In ancient portraiture general images were often used to depict faces; thus the resemblance with images in early Christianity used to depict the face of
Christ.

FIGURE 2: The blessing Christ.

It is quite understandable that Constantine's conversion in 312 changed the entire situation. According to Mathews (1993:13), the impoverished art of the catacombs and cemeteries was inadequate to express the grand claims Christians were making for their god. They appropriated the grandest imagery they could lay their hands on, namely that which developed in the service of imperial propaganda. Mathews (1993) confirms:

Finding themselves with an emperor of their own faith, Christians boldly appropriated for their own religious purposes the entire vocabulary of imperial art, transforming motifs and compositions that had been used for imperial propaganda into propaganda for Christ. (p. 13)

Inevitably, the future of Christian iconography was profoundly modified. One can say that all the vocabulary of a triumphal or imperial iconographic language was poured into the paradigms and the dictionary, which served Christian iconography (1993:13).

One can understand that this Roman cultural heritage influenced early Christian iconography and attempts to depict the Godhead. When the Bible was translated into Greek, the concept of God-pantokrator was used to depict an all-powerful God. The Latin omnipotence carried the ideology of imperial power into the formulation of the Early Church.

Bishop Eusebius of Caesarea in Palestine (c. 260 - c. 340) started to formulate for the emperor a Christian theory of divine kingship that connected close association between the lordship of Christ and the emperor's governance of the Roman Empire. Eusebious called the emperor vicegerent of Christ, an apostle for the secular sector: 'Imperial overtones in representations of Christ, then, would harmonize neatly with the philosophical theory of the emperor's divine rule' (Mathews 1993:14).

Even the church was described as the court and throne of the heavenly king (cathedral from cathedra = throne) and his representative and successor, the bishop, not to be outshone by secular pomp, practiced a clerical pomp of his own. The 'Emperor mystique' had an important theatrical dimension. It shaped the hierarchy of officials as well. The church designed its own elaborate processions, receptions, its ritual chants, hymns, sermons, attire and insignia.

It is the contention of Mathews that in essence, despite the variabilities of images of Christ in the early centuries, Christ does no imitate the emperor's depiction of power and 
display of ceremony. He presents an anti-imperial image. 'From the point of view of the Gospel narrative, then, Christ demonstrates the uselessness of imperial parades by doing an anti-imperial adventus seated on the least military of all beasts, a farmer's donkey' (Mathews 1993:45). Although this image is true according to the Gospel's portrayal of the authority of Christ, the imperial paradigm often dominated the interpretation of the omnipotence of God in the history of Christian doctrine. Royal prompt and glory and imperial governance often replaced vulnerable humility.

\section{Rather 'el Saddaj than pantokrator}

In theology, God's omnipotence has often been interpreted not in soteriological and sacrificial terms, but in Hellenistic terms: pantokrator. The latter is the Greek version of the Hebrew phrase 'el Saddaj (Hieronymus used the Latin version, deus omnipotens). It is a fact that God revealed himself several times as the Almighty. Genesis 17:1: 'the Lord appeared to him [Abraham] and said, "I am God Almighty"' (cf. Gn 28:3, 35:11, 43:14, 49:25; Ex 6:3). However, the etymology of 'el Saddaj is very complex and uncertain. ${ }^{17}$ From an exegetical viewpoint, eight possibilities exist:

- Saddaj-the terrific and strong One

- the sufficient One

- a positive Being that could be linked to an Arab word for Lord

- Saddaj that could be seen in close connection with a Semitic word for breast, the name for a fertile god

- derived from a verb that means to throw, cast or pour out

- a close link existing between Saddaj and an Accadian word for mountain - the One who comes from the high place, or from the mountain

- a link existing with a Sumerian word for God meaning: the one who knows your heart

- several scholars suggesting an Ugaritic connection with Astarte: somebody from the veld or the floor.

The only conclusion to be derived from the above exposition is that the phrase ' $\mathrm{el} \mathrm{Saddaj} \mathrm{should} \mathrm{be} \mathrm{traced} \mathrm{within} \mathrm{the} \mathrm{context}$ of the various texts. In the meantime, it must be kept in mind that it represents the uniqueness and greatness of Yahweh who reveals himself in terms of the tribal and familial metaphor, as a Father ${ }^{18}$ and God of the covenant. However, it still remains a crucial question whether Hieronymus' translation (omnipotens) and the pantokrator conception that so deeply influenced the western thought, was correct.

Van der Zee (1983:79) concludes that omnipotence, as such, does not play an important role in Scripture. The concept 'almighty God' is complex. God's omnipotence, in biblical terms, is the unique way in which God is present amongst his people. 'I would rather say: God's power is different (andersmachtig)' (1983:80, own translation). Suurmond

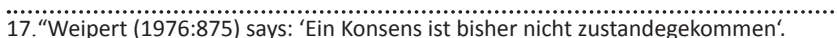
18.Weipert (1976:882) concludes: 'Es ist somit warscheinlich, dass einer de "Vatergötter" tatsächlich der ('el) gewesen ist, und P hier, wie öfter, altes Gut benutzt und generalisiert hat.'
(1984:42) remarks that the Christian God must always be a strong God. Christians would very seldom think of God as vulnerable and weak. However, vulnerability does not indicate that God is powerless; its indication that God's power is his love (love = omnipotence), is important. Omnipotence then becomes the overwhelming power of love and faithfulness that appeals to every human being's responsibility. ${ }^{19}$

According to Häring (1986:351-372), God is not a Pantokrator; neither should he be seen in terms of Aristotle's potentia. God's power is his redeeming vulnerability and powerlessness; omnipotence is God's loving invitation 'to a relationship and covenant encounter which guarantees real freedom' ${ }^{20}$

According to Van de Beek (1984:91-92), behind the concept omnipotence lies the motive to see God as the absolute One, the Super King with a driving force (despotes). Behind every event God functions as the prima causa. ${ }^{21} \mathrm{He}$ is convinced that more fundamental than Berkhofs 'weerloze overmacht' is the overwhelming phenomenon of God's majestic highness and splendid glory. ${ }^{22}$ God's dominion and sovereignty exist in the interest of humankind; his aim is to conquer the evil powers of sin and darkness. ${ }^{23}$

It can be concluded that omnipotence should not be interpreted against the background of the Hellenistic pantokrator [strength and violent power]; nor in terms of the Roman Caesar (despotes). Omnipotence describes God's unique revelation (his sovereign majesty and splendid glory), which portrays him as having overwhelming love and steadfast faithfulness. Omnipotence describes a power, which is closely connected to God's covenantal encounter and graceful identification with our human misery. Omnipotence also corresponds with righteousness and social justice. A good example of this connection can be found in Deuteronomy 10:17-19:

For the Lord your God is God of gods and Lord of lords, the great God, mighty and awesome, who shows no partiality and accepts no bribes. He defends the cause of the fatherless and the widow, and loves the alien, giving him food and clothing. And you are to love those who are alien, for you yourselves were aliens in Egypt.

19.Suurmond (1984:45) states: 'Overwinnende liefde die niet overdondert, maar bevrijdend overreedt tot een overgave die bevrijdt!',

20.Häring (1986) concludes: Macht in de oorspronkelijke zin zou dan zijn het bindende en waarheidsontsluitende karakter van iedere bestaanservaring. 'Macht' in deze betekenis bemiddelt dan de ervaring van zich met iets te kunnen inlaten, uitgedaagd te worden door wat vanzelfsprekend is, opgenomen te worden in een ruimte van beaming en van goede verstandhouding met de werkelijkheid. Noodzakelijkerwijze zijn dat tegelijk ervaringen van liefde, trouw en solidariteit. Ik stel nu: de ervaring van zulk een macht geeft vrijheid' (p. 369).

21.Van de Beek (1984:91-92) concludes that it is very difficult to eliminate the concept omnipotence. The Almighty God is, indeed, a biblical concept. The only problem is that God's dominion and sovereignty has been misused by many people. Therefore it is difficult to correlate his dominion with the suffering and injustice in history.

22.Van de Beek (1984:90) says: 'Primair is de gestalte van de majestueuze heerlijkheid, waarin God heerst.'

23.Van de Beek (1984:103) states: 'De christologie is de grote onruststoker in alle almachtsgeloof.' 
It is clear that God's transcendence is closely connected to his condescendence. Omnipotence reveals itself in history within the context of suffering and our social reality. It gives a new dimension to the concept of humanity. God shows no partiality (rendered literally, the Hebrew idiom means '...who does not lift up faces'; Craigie 1976:206), but identifies himself with our human misery: 'He defends the cause of the fatherless and the widow.' God's impartiality indicates judgement and justice as well as compassion and love for resident aliens and suffering humans. This finding corresponds with Von Rad's assertion that the Deuteronomy texts should be understood in the light of the writer's effort to gain a theoretical understanding of the relationship to Yahweh and to prove his trustworthiness. This trustworthiness of God is reflected in his loving care that safeguards his people. ${ }^{24}$

\section{Towards the dynamics of pathos- categories: Theopaschitic theology}

What is meant by the 'power of God'? Inbody's argument points towards a reinterpretation. However, and this is the primary theological question at stake, how does such a reinterpretation affect our understanding of God's very Being and reality?

It is indeed questionable whether omnipotence should be viewed as an essential description and accurate attribute of God (telling us something about God's Being - his Essence), or as a metaphor portraying God's unique faithfulness and steadfastness in relation to his covenant people. The basic theological argument is that attributes denote God's active deeds in encountering creation and human beings in the history of salvation. They do not necessarily describe God's essence as such, remote from any relation or encounter with humankind, but his relational revelation to sustain the world and his deeds of salvation to save humankind. Berkhof (1979) states:

What we may say is that what we call attributes denotes the manner in which we meet God as singular-plural, in His revelational history ... Consequently, we have to say that the attributes of God are his being itself as it is facing us. (p. 113)

When an attribute like omnipotence is derived from revelation and the covenantal encounter, it can easily fall prey to a philosophical and one-sided transcendental concept of God. Being aware of this danger, Berkhof tries to connect omnipotence with the concept defencelessness (the latter does not indicate inability or impotence, but grace that can make room for sinful human beings). In his love, God's loving power is vulnerable and prepared to take a risk with humankind. Defencelessness ${ }^{25}$ describes God's patience and long suffering. Berkhof (1979) says:

24.De Groot and Hulst (1950:117) conclude: "Heeft Abraham de naam Saddaj voordien gekend, van nu aan krijgt deze voor hem een nieuwe inhoud: die van "machtige beschermer".'

25.Berkhof (1979) postulates: 'By this [defencelessness] we understand that attribute by which he leaves room for his 'opposite' and accepts and submits himself to the freedom, the initiative, and the reaction of that 'opposite'. It has to do with the passive and receptive, the enduring and the suffering in God' (p. 134).
Defencelessness does not as such exclude an active exercise of power; it does exclude a violent and destructive (forcible) exercise of power (gewelddadige wijze) which wipes out the power of the opposite. (p. 134)

Here the very special way in which God makes his omnipotent power felt is at stake: not as a violent force (gewelddadige dwang), but as a loving compulsion (liefdevolle drang). This defencelessness is demonstrated when Jesus, renouncing all earthly power, becomes the victim of the indifference - and even hatred of his environment. Defencelessness reaches its nadir on the cross where God's vulnerability is revealed as the salvation of the world. God becomes weak (powerless; ohnmächtig, as Bonhoeffer puts it). According to Berkhof, defencelessness should be qualified. As an adjective, it does not denote powerlessness, as such. The Dutch, weerloze overmacht, is difficult to translate. Actually, overmacht does not mean superiority. Berkhof uses the term overmacht to describe God's overwhelming faithfulness and loving steadfastness. ${ }^{26}$ Instead of 'defenceless superior power' (English translation), 'vulnerable faithfulness' would be a better translation of 'weerloze overmacht'. By using overmacht, Berkhof tries to explain that God's power should be regarded as 'overwhelming grace', not as destructive and hurtful violence.

Berkhof's viewpoint impels us to ascertain whether the term almighty (which occurs only a few times and mostly in eschatological context) is understood to denote superior power in the sense of strength (God as Warrior) and oppressive authority, or overwhelming faithfulness in the sense of gracious sovereignty and unique righteousness and justice. A power then that conquers death, overcomes God's enemies and triumphs over the destructive powers of evil and darkness, hatred and injustice.

Although the terms defencelessness and vulnerability sound very strange in connection with the revelation of God, a close look at the so-called 'God theophanies' sheds new light on the whole issue of omnipotence. The theophanies of God as Warrior should be read in context; the history of salvation is the predominant issue. Primarily, God is revealed as the Bearer of the Word. God's presence is an overwhelming fact in Israel's history and his appearance in human form reveals the reality of his presence in such a way as to make him vulnerable. According to Fretheim (1984) appearance in human form:

... suggests an entering into the more vulnerable life of the world where the response can be derision (see Gen 18:12-13) or incredulity (Judg 6:13-17). It is to put oneself concretely into the hands of the world to do with as it will. It is revealing of the ways of God that the Word is enfleshed in bodies of weakness within the framework of commonplace everyday affairs and not in overwhelming power. (p. 106)

26. Note the Dutch 'maar dat God in zijn trouw blijvend handhaaft'; 'Vooral echter in de opstanding van Christus komt de overmachtige aanwezigheid van echter in de opstanding van Christus komt de overmachtige aanwezigheid van Geest op zijn eigen weerlozen wijze overmachtig bezig' (Berkhof 1977:146). 
Fretheim's conclusion (1984:106) is remarkable: 'For, even in those instances where the vestments of God's appearance are threaded with lineaments of power, they clothe in vulnerable form. There is no such thing for Israel as a non-incarnate God.'

The suffering of God is not foreign to the Old Testament. According to Fretheim (1984:139), God's suffering in the Old Testament is threefold. He suffers because of the people's rejection of him as Lord; he suffers with the people who are suffering; he suffers for them due to the fact that in the sacrifices of the Old Testament 'God gives of himself to make forgiveness possible'. Texts like Jeremiah 4:14 and 13:27, and also Hosea 6:4 and 11:8 describe God's pathos in his struggle for the future of his covenant people. God is revealed as One who is not vindictive, legalistic, or exacting as to matters of judgement. God wants life and not death (Ezk 18:23-24). Although God is deeply wounded by the broken relationship and is revealed as One who does not remain coolly unaffected by the people's rejection, the process of internalisation corresponds with God's permanent and stable faithfulness. 'God's salvific will does not waver; God's steadfast love endures forever' (Fretheim 1984:124). God remains gracious, merciful, and abounding in steadfast love.

God responds to Israel's judgement by taking up the cry of a mourner, or where suffering without judgement is in view, an empathetic presence (Jer 31:20). The most remarkable text in this regard is Leviticus 17:11, where the life of the flesh is seen to be present in the blood: '... and I have given it for you upon the altar to make atonement for your souls'. Especially striking here is that God has given life in the blood; it is God who provides the key element in the sacrifices, namely life. Fretheim (1984) comments:

Human beings thus bring not only their repentant arid trusting selves to the sacrificial act, but they are bearers of life from God. If all things belong to God, then it may be said that God gives of Himself to make forgiveness possible. In some sense, God's life is expended for the sake of the life of the people. (p. 139)

The previous exposition makes the following assertion possible: several texts suggest the theme of divine humiliation (Ps 78:61; 18:35; Is 63:9). This humiliation is connected with the eschatological character of the covenantal history. Therefore any birth of a new order can come about only through what God does and he can accomplish such a creative act only by way of a via dolorosa. This assertion corresponds with Moltmann's topic: God's suffering as a theologia crucis. ${ }^{27}$

The suffering God and the theology of the cross constitute the framework for a new paradigm, ${ }^{28}$ that is God's omnipotent presence and power interpreted as vulnerable faithfulness and overwhelming pathos. Although this sounds new, the

27.Moltmann (1972:180) postulates: 'Das Leiden und Sterben Jesu, verstanden als Leiden und Sterben des Gottessohnes, aber sind Werke Gottes gegenuber sich selbst und darum zugleich Passionen Gottes.

28.Inbody (1997:9) states: 'Although there are differences among trinitarian theologians, they all imply that the power of God is to be defined by the cross and the resurrection not by the omnipotence of theism. roots can be traced back to Martin Luther's well-known thesis (as quoted in McGrath 1985): 'The man who perceives the visible rearward parts of God as seen in suffering and the cross, does however deserve to be called a theologian. ${ }^{29}$ For Luther, the cross indeed reveals God - but that revelation is the posteriora Dei. The important thing about Luther's assertion is that the cross of Christ, in which God is found to be revealed and yet paradoxically hidden in that revelation, becomes the sole authentic locus of the human knowledge of God. The implication of this thesis is that God's strength (omnipotence) is revealed in apparent weakness, and his wisdom in folly.

It is our conviction that this thesis of Luther should be applied in the current debate on the significance of God's presence within a secularised world. It should give birth to a new paradigm about God's omnipresence. It is also applicable to contemporary theology that is looking for a new theological approach to the problem of crime, violence and conflict. A theologia crucis can help rid the church of many theological misconceptions about God's omnipotence and presence in history. It is McGrath's (1985) conviction that the theologia cruces:

passes judgement upon the church where she has become proud and triumphant, or secure and smug, and recalls her to the foot of the Cross, there to remind her of the mysterious and hidden way in which God is at work in His world. The scene of total dereliction, of apparent weakness and folly, at Calvary is the theologian's paradigm for understanding the hidden presence and activity of God in His world and in His church. (p. 181)

\section{From omniscience to infiniscience: Theology of the intestines}

In the effort to identify God with human suffering, theopaschitism became the theory or doctrine by which theology tries to construe a more passionate approach to our understanding of God's presence within the reality of human suffering (injustice, poverty, stigmatisation, discrimination, stereotyping, illness, violence, the abuse of power, tsunamis, catastrophes).

Those theologians who wanted to reframe paradigms regarding God's praxis have welcomed a theopaschitic approach..$^{30}$ No longer is God seen as static and absolute, but dynamic, thereby opening up the future for human existence. $^{31}$ The value of theopaschitic thinking for the praxis of God is that it proposes a shift from the substantial approach to the relational and encounter paradigm (Berkhof 1979:32-33). The switch is then from the attempt of orthodoxy

29. Luther (quoted in McGrath 1985) states "Sed qui visibilia et posteriora Dei per passiones et crucem conspecta intelligit.

30.Some of the most important proponents of theopaschitism are the following: God's weakness (Bonnhoeffer 1951); God's powerlessness (Sölle 1973); God's being as an event of becoming (Gottes Sein ist im Werden; Jüngel 1967); God's forsakenness (Moltmann 1972); God's defencelessness (Berkhof 1977; Wiersinga 1972).

31.Although the pathos concept suggests evidence of God's genuine involvement in suffering, there is a danger that the distinction between the passio Dei and the passio hominum can easily fall away. God's sovereignty (transcendence) can the passio hominum can easily fall away. God's sovereignty (transcendence) can (condescension). 
to uphold ecclesial triumphantilism (Hall 1993:100-101) and a theology of glory (theologia gloriae) and omnipotence (powerful force), ${ }^{32}$ to a theologia crucis $^{33}$ of weakness, suffering and passion.

It is my contention that the passio dei is a theological exposition of the praxis of hope in caregiving. The passio dei, in its connection to the praxis of God, defines 'practice' in practical theology to compassion ( $\mathrm{rhm}$ in close connection to the root $h n n$, which means to be gracious). Together with oiktirmos and praxis, the passio dei expresses the being quality of God as connected to human vulnerability and suffering (Esser 1978:598). The verb splanchnizomai is used to make the unbounded mercy of God visible.

Ta splanchna reveals God as a Presence, 'a Companion, "your God"' (Hall 1993:147). In praxis thinking it is not the task of the church to demonstrate that God must be, but to bear witness to God's being-there, being-with, and being-for the creature. In terms of Hall (1993:155), the test of the church's God-talk at any point in time is its contextual authenticity, its praxis-thinking: Does it illuminate God's being-with-us? We can add: Does it portray God's being-with-us as ta splanchna and thus as a source of hope and meaning?

In general, Greek to splanchnon refers to the valuable parts, the heart, lung, liver, but also the spleen and the kidneys. During the sacrifice, they are removed for the sacrificial meal. With reference to human splanchna, it refers to the human entrails, especially for the male sexual organs and the womb, as the site of the powers of conception and birth. Within metaphoric speech, ta splanchna expresses pity, compassion and love: 'The oldest form of the verb is splanchneuo, eat the entrails, prophesy from the entrails' (Esser 1978:599). Within the messianic context of Christ's salvific mission, ta splanchna expresses compassion as an indication of God's divine involvement with the human predicament of suffering. ${ }^{34}$

Splanchnizomai reveals the very character of God within the messianic involvement and engagement with human suffering. The theology of the entrails reflects God's being quality, and can be called the ontology of God's attitude in suffering. Noteworthy is the fact that within these texts ta splanchna is connected to illness and health; dying and mourning; loss and grief; violence and injustice; burnout and hunger, estrangement and remorse.

32.See in this regard the remark of Hall (1993:108): "Powerful people demand powerful deities - and get them!'; and 'Power - and precisely power understood in the usual sense - is of the essence of divinity shaped by empire' (1993:107).

33.'Greek epistemology could not take account of the surprise needed to recognize God on the cross ... It did not envision suffering as a source of knowledge' (Jon Sobrino quoted in Hall 1993: note 8, p. 105).

34.It is interesting to note the cases where Christ responded to human suffering with the contraction of the entrails, expressing messianic compassion. For example the leper with his petition (Mk 1:41); the people like sheep without a shepherd (Mk 6:34); the sight of the harassed and exhausted crowd (Mt 9:36); two blind men who besought him (Mt 20:34); the widow at Nain mourning her only son (Lk 7:13). In Luke 15:11-32 the prodigal son, splanchnizomai expresses the strongest feeling of a merciful and loving reaction (v. 20). In the parable of the Good Samaritan (LK of a merciful and loving reaction ( $v$. 20). In the parable of the Good Samaritan (LK
10:33) splanchnizomai expresses the attitude of complete willingness to use all 10:33) splanchnizomai expresses the attitude of complete willingness to use all
means, time, strength, and life, for saving at the crucial moment (Esser 1978:600).
From a practical point of view, the general and traditional theological question is always the cause-effect question, namely why God, and whether God is behind these cases. From a praxis point of view, the question is not whether God is behind these events, but how he is involved. What is God's attitude and intention within these events?; What is the mode of God's being within our human predicament? The notion of ta splanchna and infiniscience as a vivid mode of splanchnizomai totally reframes our understanding of who God is and what is meant by God's power. Instead of threat, power (a Caesar-like display of imperialistic strength ${ }^{35}$ pantokrator), divine power is now understood as passion and compassion (oiktirmos).

By his suffering, God shows that he is weak, vulnerable and powerless in this world. Only Christ's weakness can help us to resist suffering in an attitude of protest, resistance and surrender (Bonnhoeffer: 1951 Widerstand und Ergebung). The theopaschitic approach clearly links God with suffering. The cross completes this link and this reveals God as a 'pathetic' being: he is the 'suffering God'. Feitsma (1956) calls this form of theopaschitism (redefining God's Being in terms of suffering) the most ultimate expression in theology of what is meant by God's compassion. ${ }^{36}$

\section{Conclusion}

Ta splanchna describes the praxis of God's being not in substantial categories, but in terms of passion categories: compassion (oiktirmos). Ta splanchna is about a theological beautification of life and could theologically be rendered as a sustainable involvement in all forms of human misery. It describes the aesthetics of a suffering God. In this regard, Browning's reference (1983:13) to David Tracy's conviction that practical theology has primarily to do with the criteria or norms for the transformation of human brokenness, is addressed. Our human suffering and the quest for meaning determines all forms of praxis-thinking. The praxis in praxisthinking is the enfleshment of compassion through the inhabitational presence of God within human embodiment (pneumatological sustainability).

In this regard, the biblical text in Philippians 2:1-2 plays a fundamental role in the choice of pastoral care, cura animarum as compassionate fellow-suffering and an exhibition of kenotic, self-emptying love:

35 . Inbody (1997:140) captures this problem very aptly when he argues that in our attempt to rethink the meaning of divine power, two things can happen. Our Godattempt to rethink the meaning of divine power, two things can happen. Our Godimage can become 'too small', or 'too big'. If God can only empathise with the
suffering of the world, but can do nothing about it, God is too small. If God is suffering of the world, but can do nothing about it, God is too small. If God is
identified with nature, and can do nothing more than what positivists mean by identified with nature, and can do nothing more than what positivists mean by
natural law, God is too small. If God is identified with human capacities, abilities, creativity or human ideals, then God is minimalised. On the other hand, if God is identified with omnipotent power, as the kind of power that, because of definition, can do 'just anything', God is too big. When a theistic notion of divine omnipotence portrays God's kingdom in terms of an empire, he becomes too militant and strong. God is then merely a Hellenistic pantokrator.

36.Feitsma (1956:42) denotes: 'Maar als we de noemer aldus onder woorden brengen: natural divina passa est, dan moeten toch al die vormen op deze noemer gebracht worden.' Cf also Feitsma's (1956) observation: Ook in het modern theopaschitisme horen we steeds weer dat geluid van Gods eigen lijden. En dat niet als een consequentie van communicatio idiomatum in de ene hypostase van Hem die God en mens is (wie langs deze weg komt tot het spreken over Gods lijden kan zich daarvoor op de Schrift beroepen), maar als typering van Gods diepste wezen. (p. 143) 
If then there is any encouragement/consolation (paraklēsis) in Christ, any comfort/consolation from love, any sharing/ fellowship in the Spirit (koinōnia Pneumatos), any compassion/ affection and sympathy/mercy (ei tis splanchna kai oiktirmoi), fulfil my joy (make complete): be of the same mind (being likeminded) (phronēte), having the same love, being in full accord and of one mind (phronountēs).

Divine compassion is expressed by the God-image of God as our Compassionate Companion, Host or Friend for Life. The ontological realm of the aesthetics praxis of God is described by means of metaphorical speech. In this regard, the notion of 'bowel categories' describes a practical theology of the intestines. The intention and motivation within praxisactions is the passio Dei. With reference to Vincent Brümmer, one can say the passio Dei expresses the meaning of Christian faith and is the concrete praxis hermeneutics of the amicitia Dei (Brümmer 2006:299-302): 'It is only by loving God that we can achieve ultimate happiness and complete fulfilment in our lives' (2006:299).

The theological telos [teleology] for 'fides quaerens spem' is hesed and ta splanchna, that is the compassionate humanist or humane praxis of the covenantal God as expressed in the promissio and fulfilment of the Crucified and Suffering Servant: Jesus Christ the Son of God; God Emmanuel, the Fellow-Sufferer.

The eschatological convergence point of the passio dei as described by splanchna, hesed, rhm, oiktirmos, pascho, is the lament of God in the derelictio-cry of the Suffering Servant at the cross. This is the reason for Jürgen Moltmann founding his theory of a theology of hope in the notion of an eschatologia crucis.

With reference to the notion of a functional, practicaltheological ecclesiology, functionality and efficiency should be directed by a God-concept that promote a kind of divine presence that embrace paradox and the unpredictability of randomness, rather than to explain on a rational level the unusual events of life. It is in this regard that compassionate interventions in caregiving do not describe fixed theological principles; they rather point to what one can call infinisciences of divine engagements (ongoing modes of divine interventions through and by the indwelling Spirit of God within the functions of the church as expressions of God's presence in this world). Infiniscience is in essence a pneumatological concept and thus should be rendered as a category that represents an ongoing intervention that, in terms of the promissio of God, safeguards a continuum of divine sustainability

The further theological implication of such divine infinisciences is that the concept 'praxis of God' is demarcated by suffering. The challenge in a practical theological reflection on the notion 'the praxis of God' is how to link the infiniscience of God to suffering.

Within an 'open system', the focus is not on 'omniscience' and 'omnipotence', rather on infiniscience: the unexpected but ongoing events of life as well as the explosion of new integrative complex systems of creative change and hoping. In such an 'open system', the methodological implication for practical theology is a circular approach within the hermeneutics of a spiral model and zigzag methodology of interpretation, rather than the limitations of either a bottomup approach (the experiential, phenomenological model) or a top-down approach (the theistic, static model). 'To clarify, Platonic is top-down, formulaic, closed-minded selfserving, and commoditized; a-Platonic is bottom-up, openminded, sceptical, and empirical' (Taleb 2012:182). Pathetic is zigzag and spiral due to compassionate networking and the paradoxical character of kenotic love and consolatory beingwith.

With reference to the connection between complexity and paradigm shifts in theory formation, the following remark was made: Within an 'open system' the focus is not on the 'omniscience' and 'omnipotence' of God, but rather on the infiniscience of God. Infiniscience points to the ongoing intervention of God and steadfast faithful presence of God in all spheres of life. The concept 'God' (Yahweh) as an active verb (to be) is a kind of unexpected, merciful happenstance within the ongoing events of life. Within the explosion of new integrative complex systems of creative change and hoping, the presence of God surfaces as the amazing discovery and promise in the Old Testament: 'I will be your God' and 'I am who I am, and I shall be there wherever you are'.

Sustainability in its connection to the intervening actions of God's oiktirmos and hesed point to infinitive of God's being there within out human vulnerability. The 'infiniscience of God' thus refers to his compassionate being-with within the predicament of our being human. It is an indication of faithfulness and a source of vivid hope. The deity in the kingdom of Pharaoh is framed by 'remote stagnation'; the deity in Israel is framed by promises of freedom (Exoduscategories).

\section{In a nutshell}

Due to the fact that the name of God refers more to a verb in the continuous tense than a fixed substance in the past tense, the following theological paradigm shift is proposed: from the omniscience of God to the infiniscience of God. The infiniscience of God indicates that his power is less about a causative threat-power and more about a compassionate comfort-empowerment; infiniscience displays sustainable and ongoing faithfulness and grace. God is the living God within the covenantal inifiniscience: the God of Abraham, Isaac, and Jacob. The fact is that the hesed and oiktirmos of God have implications for both the naming of God in the praxis of caregiving, as well as for a Christian anthropology and divine interventions within sociocultural processes of change. Hesed and oiktirmos define God as a Compassionate Companion and Intimate Partner for spiritual wholeness in life; they define human beings as agents and beacons of hope and wounded healers of life despite the zigzag patterns of suffering. 
In theory formation for a theology of compassion and hope, omni-categories should make place for encounter and embracement categories. Rather the notion of the infiniscience of God (the noun Jahwēh from the verb haja in Hebrew = to be; God as verb and the infinitive tense as indication of a continuous being-with and a promise of covenantal faithfulness), than the speculative omniscience of God (the positivism of all-knowing as a rational, explanatory category). The infinitive tense of God's faithful being-with operates like an unprobable factor in life; it represents a kind of Black swan event that runs contradictory to any form of positivistic prediction and expectation.

In Christian spirituality, the involution of wisdom and the involuntariness of hope are connected to the infiniscience of God; to the covenantal promise for continuous but unexpected sustainability: I will continually be there where you are; I will be your God (the sustainability of divine faithfulness) even within the disorder of chaotic life events.

\section{Acknowledgements Competing interests}

The author declares that he has no financial or personal relationship(s) that may have inappropriately influenced him in writing this article.

\section{References}

Altizer, J.J. \& Hamilton, W., 1966, Radical theology and the death of God, BobbsMerrill, New York.

Armstrong, K., 1997, A history of God from Abraham to the present: The 4000-year quest for God, Mandarin, London.

Barnard, M., Cilliers, J. \& Wepener, C., 2014, Worship in the network culture: Liturgical ritual studies - Field and methods, concepts and metaphors, Peeters, Leuven.

Belgic Confession, 1959, Psalter hymnal: Doctrinal standards and liturgy of the Christian Reformed Church, Publication Committee of the Christian Reformed Church, Grand Rapids.

Berkhof, H., 1977, Christelijk geloof, Callenbach, Nijkerk.

Berkhof, H., 1979, Christian faith, Eerdmans, Grand Rapids.

Bonnhoeffer, D., 1951, Widerstand und Ergebung, Kaiser Verlag, München.

Bons-Storm, R., 1996, The incredible woman: Listening to women's silences in pastora care and counseling, Abingdon Press, Nashville.

Browning, D.S., 1983, 'Pastoral theology in a pluralistic age', in D.S. Browning (ed.), Practical theology, Harper \& Row, San Francisco.

Brümmer, V., 2006, Brümmer on meaning and the Christian faith, Ashgate, Aldershot.

Burkey, J., 2010, 'A review of Richard Kearney's anatheism: Returning to God after God', Journal of Cultural and Religious Theory 10(3), 160-166.

Capps, D., 1984, Pastoral care and hermeneutics, Fortress, Philadelphia.

Cox, H., 1965, The secular city, SCM, London.

Cox, H., 1969, The feast of fools: A theological essay on festivity and fantasy, Harper \& Row, New York.

Craigie, P.C., 1976, The book of Deuteronomy, Eerdmans, Grand Rapids.

Critchley, S., 2012, The faith of the faithless: Experiments in political theology, Verso, London.

Davies, O., 2001, A theology of compassion: Metaphysics of difference and the renewal of tradition, Eerdmans, Grand Rapids.

De Groot, J. \& Hulst, A.R., 1950, Macht en wil, Callenbach, Nijkerk.

Esser, H-H., 1978, 'Splanchna', in C. Brown (ed.), Dictionary of New Testamen theology, vol. 2, pp. 599-601, Paternoster Press, Exeter.

Evans, H., 2004, 'Faith and power 1261-1557', in H.C. Evans (ed.), Byzantium: Faith and power, Metropolitan Museum of Art, New York.

Feitsma, M., 1956, Het theopaschitisme: Een dogma-historische studie over de ontwikkeling van het theopaschitisch denken, Kok, Kampen.

Fretheim, T.E., 1984, The suffering of God, Fortress, Philadelphia.

Gombrich, E.H., 2006, The story of art, Phaidon, London.
Hall, D., 1993, Professing the faith, Fortress, Minneapolis.

Häring, H., 1986, 'Het kwaad als vraag naar Gods macht en machteloosheid', Tijdschrift voor Theologie 26(4), 351-372.

Harland, P.A., 2009, Dynamics of identity in the world of the early Christians, Clark, New York.

Inbody, T., 1997, The transforming God: An interpretation of suffering and evil, Westminster John Knox, Louisville.

Johnson, P., 1985, A history of the modern world: From 1917 to the 1980s, Jonathan Ball, Johannesburg.

Jüngel, E., 1967, Gottes Sein ist im Werden, Mohr (Siebeck), Tübingen.

Kearney, R., 2011, Anatheism: Returning to God after God, Columbia University Press, New York.

Kopp-Schmidt, G., 2004, Iconograpahie und Ikonologie: Eine Einführung, Deubner Verlag für Kunst, Köln.

Krause, B., 1980, Leiden Gottes - Leiden des Menschen: Eine Untersuchung zur kirchlichen Dogmatik Karl Barths, Calwer, Stuttgart. (Calwer theologische Monographien 6)

Krog, A., 1998, Country of my skull, Random House, Johannesburg.

Küng, H., 1970, Menschwerdung Gotttes: Eine Einführung in Hegels theologisches Denken als Prolegomena zu einer künftigen Christologie - Ökomensiche Forschungen, 2 Soteriologische Abteilung, Band 1, Herder, Freiburg im Breisgau.

Lawston, G., 2014, 'Losing our religion', New Scientist, 30-35.

Louw, D.J., 2000, Meaning in suffering: A theological reflection on the cross and the resurrection for pastoral care and counselling, Peter Lang, Frankfurt am Main.

Mathews, T.F., 1993, The clash of Gods: A reinterpretation of early Christian art, Princeton University Press, Princeton.

Mathews, T.F., 1998, Byzantium: From antiquity to the Renaissance, Yale University Press, New Haven.

McFague, S., 1987, Models of God, Fortress, Philadelphia.

McGrath, A.E., 1985, Luther's theology of the cross: Martin Luther's theological breakthrough, Blackwell, Oxford.

Miller-McLemore, B.J., 2012, 'Introduction: The contributions of practical theology', in B.J. Miller-McLemore (ed.), The Wiley-Blackwell Companion to Practical Theology, pp. 1-20, Wiley-Blackwell, Oxford

Moltmann, J., 1972, Der gekreuzigte Gott, Kaiser, München.

Moore, Z.B., 2002, Introducing feminist perspectives on pastoral theology, Sheffield Academic Press, Sheffield.

Müller, J.C., 2011, 'Postfoundational practical theology for a time of transition', HTS Teologiese Studies/Theological Studies 67(1), 1-5. http://dx. doi. org/10.4102/hts. v67i1.837

Nauer, D., 2010, Seelsorge: Sorge um die Seele, Kohlhammer, Stuttgart.

Nyssen, W., 1982, 'Die theologische und liturgische Bedeutung der Ikonen', in K. Weitzman et al., Die Ikonenen, pp. 413-416, Herder Verlag, Freiburg im Breisgau.

Pasewark, K.A., 1993, A theology of power: Being beyond domination, Fortress, Minneapolis.

Process Theology, 2015, 'Process theology', viewed 20 May 2015, from http:// en.wikipedia.org/wiki/Process_theology.

Reader, J., 2008, Reconstructing practical theology: The impact of globalization, Ashgate, Aldershot.

Robinson, J.A.T., 1963, Honest to God, SCM, London.

Ruther, R.R., 2002, 'The emergence of Christian feminist theology', in S.F. Parsons (ed.), Feminist theology, pp. 3-22, Cambridge University Press, Cambridge.

Sölle, D., 1973, Leiden, Kreuz, Stuttgart.

Suurmond, P.B., 1984, God is machtig - Maar hoe?, 2e dr., Ten Have, Baarn.

Taleb, N.N., 2010, The black swan: The impact of the highly improbable, Penguin Books, London.

Taleb, N.N., 2012, Antifragile: Things that gain from disorder, Penguin Books, London. Tillich, P., 1965, The courage to be, Collins, London.

Tutu, D. 2004, 'Nelson Mandela annual lecture', viewed 20 September 2014, from http://nelsonmendela.org/uploads/files/NMF_Lecture_Book_small.pdf.

Van de Beek, A., 1984, Waarom? Over lijden, schuld en God, Callenbach, Nijkerk.

Van der Zee, W.R., 1983, Wie heeft daar woorden voor?, Boekencentrum, 's-Gravenhage.

Van Huyssteen, J.W., 1997, Essays in postfoundationalist Theology, Eerdmans, Grand Rapids.

Van Huyssteen, J.W., 2015, “"Practicing Ubuntu”: God, morality, and persoonhood - A bottom-up approach'. Unpublished Keynote Address, International Academy of Practical Theology (IAPT), July 20, Pretoria.

Velmans, T., 2007, Byzanz: Kunst und Architektur, Michael Imhof, Petersberg.

Weipert, M., 1976, '“addonaj", Gottesname', in E. Jenni \& C. Westermann (Hrsg.), Theologisches Handwörterbuch zum Alten Testament, T. 2, Kaiser, München.

Weitzman, K., 1982, 'Ursprung und Bedeutung der Ikonen', in K. Weitzman et al., Die Ikonenen, pp. 5-19, Herder Verlag, Freiburg im Breisgau.

Wiersinga, H., 1972, Verzoening als verandering, Bosch \& Keuning, Baarn.

Zakssaya, V., 2006, 'The classical heritage in Byzantine art', in K. Weitzman, The road to Byzantium: Luxury arts of antiquity, pp. 49-57, Fontana (Somerset House), London. 